\title{
Oposição política, novatos e insucesso eleitoral: Partido Republicano Liberal (Paraná, Brasil: 1923-1924)
}

DOI: 10.15175/1984-2503-202214106

\section{Sandro Aramis Richter Gomes ${ }^{*}$}

\begin{abstract}
Resumo
Neste artigo é desenvolvida uma investigação sobre os processos de criação e dissolução do Partido Republicano Liberal (PRL). Tal agremiação existiu no Estado do Paraná, de 1923 a 1924. Por meio de um estudo de caso, a finalidade deste trabalho é avançar na compreensão das formas de ação eleitoral das oposições estaduais nos anos finais da Primeira República. Há três argumentos sustentados nesta análise. Primeiro, é demonstrado que o PRL era controlado por novatos da cena política. Eles não obtiveram o apoio de oposicionistas históricos para estruturar a agremiação. Segundo, cumpre evidenciar que esse partido teve a menor duração e o desempenho eleitoral mais fraco dentre as agremiações minoritárias criadas no Paraná ao tempo da Primeira República. Terceiro, trata-se de salientar que a extinção da grei foi sucedida pelo fim da atividade política da maior parte de seus dirigentes.
\end{abstract}

Palavras-chave: Estado do Paraná; oposicionistas; partidos políticos; Primeira República.

Oposición política, falta de experiencia y fracaso electoral: los procesos de constitución y extinción del Partido Republicano Liberal (Es tado de Paraná, 1923-1924)

\section{Resumen}

En este artículo se desarrolla una investigación sobre los procesos de creación y disolución del Partido Republicano Liberal (PRL), que existió en el Estado de Paraná, entre 1923 y 1924. A través de un estudio de caso, el propósito de este trabajo es comprender mejor las formas de actuación electoral de los partidos estatales de la oposición en los últimos años de la Primera República de Brasil. El análisis se apoya en tres argumentos. En primer lugar, se demuestra que el PRL estaba controlado por personas sin experiencia en la escena política que no contaban con el apoyo de opositores históricos para estructurar el partido. En segundo lugar, cabe señalar que se trató de la organización de menor duración y con resultados electorales más bajos de entre los grupos minoritarios creados en Paraná en la época de la Primera República. En tercer lugar, es importante hacer hincapié en que su extinción supuso el fin de la actividad política de la mayoría de sus líderes.

Palabras clave: Estado de Paraná; oposicionistas; partidos políticos; Primera República de Brasil.

\footnotetext{
* Professor e pesquisador de Pós-Doutorado no Programa de Pós-Graduação em História da Universidade Federal do Paraná. Graduado em História (2009), mestrado (2012) e doutorado (2017) em História pela Universidade Federal do Paraná (UFPR). E-mail: argomes8@gmail.com.

http://lattes.cnpq.br/2071519123932874. ㄴ. https://orcid.org/0000-0002-6790-4958
}

Recebido em 01 de fevereiro de 2021 e aprovado para publicação em 05 de janeiro de 2022. 


\begin{abstract}
The following article develops an investigation into the processes by which the Liberal Republican Party (LRP) was created and dissolved, with such an association existing in the state of Paraná from 1923 to 1924. By means of a case study, the aim of this work is to develop an understanding of the electoral initiatives caried out among state oppositionists in the final years of the First Brazilian Republic. There are three arguments sustained in this analysis. First, the article demonstrates that the LRP was controlled by newcomers to the political scene who did not obtain the support of historic oppositionists in structuring the association. Second, evidence suggests that this party was shortest in duration and poorest in performance in elections among the minority associations created in Paraná during the First Brazilian Republic. Third, it must be highlighted that the group's extinction was followed by an end in political activities for most of its adherents.
\end{abstract}

Keywords: State of Paraná; oppositionists; political parties; First Brazilian Republic.

\title{
Opposition politique, néophytes et échec électoral : processus de constitution et d'extinction du Parti républicain libéral (État du Paraná, 1923-1924)
}

\section{Résumé}

Cet article propose une recherche sur les processus de création et de dissolution du Parti républicain libéral (PRL), qui a existé dans l'État du Paraná de 1923 à 1924. Par l'intermédiaire d'une étude de cas, la finalité de ce travail est d'avancer dans la compréhension des formes d'action électorale des oppositions régionales lors des dernières années de la Première République. Trois arguments soutiennent cette analyse. En premier lieu, nous montrerons que le PRL était contrôlé par des néophytes de la scène politique, qui n'ont pas réussi à obtenir le soutien d'opposants historiques pour structurer leur parti. Dans un second temps, on montrera que ce parti a été le plus éphémère et le moins performant en matière électorale parmi les partis minoritaires créés dans l'État du Paraná à l'époque de la Première République. II s'agira enfin de souligner que l'extinction du parti a été suivie par la fin de l'activité politique de la plupart de ses dirigeants.

Mots-clés : État du Paraná ; opposants ; partis politiques ; Première République .

\section{政治反对派、新来者和选举失败：自由共和党的成立与消亡(巴拉那州, 1923-1924 年)}

\section{摘要}

$\begin{array}{llllll}\text { 本文调查了自由共和党 } & (\mathrm{PRL}) \quad \text { 的创建和解散过程。该党派于 } & 1923 & \text { 年至 } & 1924\end{array}$ 年期间在巴西南部的巴拉那州成立。通过此案例研究，本文目的是分析巴西第一共和国(18891930)最后几年里，巴西各州反对派的选举行动。我们的分析结果表明，首先，自由共和党 是由政治舞台上的新人所组建并控制的。他们在创党过程中并没有得到“历史反对派”的支持。其次，在第一共 和国时期，在巴拉那州成立的所有的少数派政党中，该党的存在时间最短，选举表现最差。第三，该党的解散 是由于党的大多数领导人的政治活动结束，因而解散。

关键词: 巴拉那州；反对派；政党；巴西第一共和国 


\section{Introdução}

Neste artigo é realizada uma investigação acerca dos processos de fundação e extinção do Partido Republicano Liberal (PRL). Essa agremiação existiu no Estado do Paraná, de 1923 a 1924. O objetivo deste estudo é produzir um conhecimento sobre a ação eleitoral das oposições estaduais nos anos correspondentes ao fim da Primeira República.

Há três argumentos fundamentados neste trabalho. Primeiro, trata-se de evidenciar que o PRL foi uma agremiação comandada majoritariamente por novatos da cena política. Essa grei não contou com relevante apoio de antigos adversários do partido situacionista do Paraná. Segundo, é demonstrado que o desempenho eleitoral do PRL foi menos expressivo do que o das demais agremiações minoritárias que existiram nesse estado na época da Primeira República. O terceiro argumento salienta que foi pouco duradoura a unidade política dos líderes da grei. A extinção do partido provocou a desagregação desses correligionários.

Os estudos históricos têm dedicado atenção ao tema da competição eleitoral no contexto da Primeira República. A análise das formas de combate aos partidos situacionistas é um elemento central de tais estudos. Um dos recentes avanços dos trabalhos sobre a história política brasileira consiste no reconhecimento de analogias quanto às formas de ação eleitoral das oposições regionais na mencionada época. Dentre tais formas, estava a contestação dos resultados eleitorais em agências como a Comissão de Verificação de Poderes da Câmara dos Deputados (ZULINI, 2016).

A historiografia tem evidenciado que, em distintos estados, havia grupos oposicionistas permanentemente organizados. Tal organização permitiu que postulantes de partidos minoritários suplantassem, ainda que circunstancialmente, os candidatos ligados às agremiações oficiais (FIGUEIREDO, 2017). Nesse âmbito, compete ressaltar que as análises históricas têm avançado no entendimento das dinâmicas políticas regionais nos períodos referentes ao limiar e aos anos finais da Primeira República. Um dos resultados centrais desses trabalhos evidencia que, em ambos os períodos, havia partidos de oposição suficientemente coesos para disputar sucessivas eleições e combater as agremiações dominantes (BRITO, 2019; RIBEIRO, 2019; SACCOL, 2018; SÁ PINTO, 2011).

De outra parte, trata-se de destacar três limitações inerentes aos estudos alusivos à vida político-partidária da Primeira República. Uma limitação é atinente à análise da formação e desorganização dos partidos de oposição. Permanece pouco desenvolvida a tarefa de 
identificar os fatores da longevidade ou da breve duração de agremiações minoritárias (PRADO, 1986). Por consequência, remanesce em estágio incipiente a comparação entre os partidos oposicionistas quanto à maior ou menor estabilidade de sua vida interna.

A segunda limitação é referente à análise de campanhas e resultados eleitorais. É pouco frequente a realização de estudos voltados ao entendimento das oscilações no desempenho eleitoral de partidos de oposição (NOLL; TRINDADE, 2004). A historiografia se ressente da falta de análises que evidenciem as diferenças regionais quanto ao nível de competitividade eleitoral dos adversários de partidos dominantes.

Por fim, a terceira limitação diz respeito à análise das carreiras políticas de lideranças oposicionistas. No âmbito dos estudos sobre a história política paranaense, a adoção dessa linha de investigação permanece pouco usual. Essa vertente de abordagem favorece o reconhecimento de distinções regionais quanto à maior ou menor inclinação de desses líderes serem cooptados pelos partidos majoritários. Tal análise também é decisiva para reconhecer os fatores da ascensão e da substituição dos chefes dos pequenos partidos.

Para a realização de tal abordagem, o presente artigo emprega métodos de análise inspirados na prosopografia (CHARLE, 2006; STONE, 2011). ${ }^{1}$ Convém, pois, destacar semelhanças quanto aos percursos políticos e sociais dos próceres do PRL. A identificação dessas semelhanças permite o entendimento das condições de ingresso no jogo político no Paraná dos anos 1920. Ela também favorece o reconhecimento de aproximações entre tais indivíduos quanto aos seus destinos após a dissolução da grei. Assim, é ressaltado que havia uma convergência entre esses dirigentes partidários no que concerne às oportunidades políticas e sociais que obtiveram desde a época anterior à fundação do PRL.

\section{A vida política paranaense no início dos anos 1920: a desmobilização dos antigos líderes oposicionistas}

O estudo da estruturação do PRL requer, inicialmente, a formulação de um panorama acerca do cenário político do Paraná no início da década de 1920. Para tanto, cumpre sustentar três constatações. Primeiro, trata-se de salientar que, do fim dos anos 1900 ao começo dos anos 1920, os partidos oposicionistas que existiram nesse estado 
foram comandados por egressos da agremiação situacionista. Tal agremiação era denominada de Partido Republicano Paranaense (PRP).

Por um lado, cabe destacar que o campo oposicionista não foi o espaço para a emergência de novas lideranças políticas. No referido estado, tal campo era o refúgio para que governistas decaídos pudessem se manter politicamente ativos. Por outro lado, cumpre mencionar que os partidos minoritários tiveram curta duração. No período em tela, a vida política paranaense foi marcada pela constante mudança no rol dos próceres da oposição.

Para atestar tais afirmações, convém ressaltar que data de novembro de 1908 a fundação do Partido Republicano Federal (PRF). Essa grei era presidida pelo médico Randolfo Pereira de Serzedelo (1862-1919), que fora membro do PRP. Entretanto, o PRF se extinguiu seis meses após a sua fundação. Ele jamais elegeu um candidato. Em maio de 1909, essa agremiação já se encontrava desativada (DIÁRIO DA TARDE, 31 maio 1909, p. 1).

Ao longo dos anos 1910, surgiram dois partidos de oposição no estado. Em 1913, ocorreu a fundação do diretório paranaense do Partido Republicano Liberal (PRL). Ele era uma agremiação nacional. O seu líder maior era o senador baiano Rui Barbosa. No Paraná, o PRL era presidido pelo jornalista Manuel Correia de Freitas (1851-1932) (DIÁRIO DA TARDE, 31 out. 1913, p. 2). Apoiado pelos governistas, esse dirigente conseguiu se elegera deputado federal em 1909 (A REPÚBLICA, 02 mar. 1909, p. 1). Em suma, Correia de Freitas se enquadrava no perfil de um governista dissidente que alcançou a condição de chefe partidário ao migrar para a oposição.

As atividades do PRL paranaense não se estenderam para além do primeiro semestre de 1915. No início de tal ano, a agremiação se cindiu (DIÁRIO TARDE, 26 jan. 1915 , p. 2). Um motivo capital da extinção da grei consistiu na transferência de parte de seus dirigentes para o campo situacionista (A REPÚBLICA, 12 fev. 1915, p. 1). Por consequência, houve o crescimento da bancada governista no Congresso Estadual (GLASSER, 1955). Em última análise, foram pouco consistentes as alianças estabelecidas entre os contendores do governismo paranaense no curso dos anos 1910.

Nessa época, o político que permaneceu por mais tempo no controle das atividades eleitorais da oposição paranaense foi o advogado Manuel de Alencar Guimarães (1865-1940). Em fins de 1914, época em que exercia mandato de senador, ele

\footnotetext{
${ }^{1}$ As fontes utilizadas neste trabalho consistem em anais parlamentares e jornais de circulação regional e nacional. Essas fontes estão disponíveis para consulta no sítio eletrônico da Hemeroteca da Biblioteca Nacional.
} 
abriu uma dissidência no PRP. Nessa ocasião, tal parlamentar não conseguiu incluir na chapa do PRP os candidatos de sua preferência à Câmara dos Deputados. Em seguida, desligou-se da agremiação (GUIMARÃES, 1915). Em tal contexto, Guimarães vivenciava o declínio de sua influência no núcleo dirigente do partido situacionista do Paraná. Dessa forma, as querelas derivadas do preenchimento de chapas de candidatos e da competição por posições na Mesa Diretora do diretório central do PRP motivavam o desligamento de correligionários.

No início de 1915, Alencar Guimarães criou uma frente oposicionista denominada Coligação Republicana (A REPÚBLICA, 21 jan. 1915, p. 2). No segundo semestre de tal ano, o então senador instalou no Paraná um diretório do Partido Republicano Conservador (PRC) (DIÁRIO DA TARDE, 09 ago. 1915, p. 1). O dirigente nacional dessa grei era o senador José Gomes Pinheiro Machado, do Rio Grande do Sul (1851-1915) (BORGES, 2004).

Analogamente às agremiações oposicionistas que a precederam, o PRC paranaense foi marcado por dissídios entre os seus líderes. Em 1918, os confrontos decorrentes da indicação de candidatos a eleições parlamentares provocaram a dissolução do diretório regional do partido (DIÁRIO DA TARDE, 01 fev. 1918, p. 1). Entretanto, o encerramento das atividades do PRC paranaense não pôs fim à liderança de Alencar Guimarães no campo da oposição.

Em 1919, esse parlamentar fundou o Partido Autonomista. Em 1921, após sucessivas derrotas eleitorais, essa grei se extinguiu (GAZETA DE NOTÍCIAS, 02 mar. 1921, p. 3). O fim da agremiação motivou a desagregação das antigas lideranças da oposição estadual. Naquele ano, os oposicionistas não lançaram candidatos ao Congresso Legislativo do Paraná (A REPÚBLICA, 03 nov. 1921, p. 1). Por consequência, o predomínio do PRP na vida política regional se tornou mais acentuado. No início dos anos 1920, permaneciam volúveis as relações entre os adversários do governismo. Contrariamente ao jogo eleitoral de áreas como o Distrito Federal, em tal época não havia o equilíbrio de forças entre as agremiações concorrentes no Paraná. ${ }^{2}$

Cumpre, pois, fundamentar a segunda constatação desta seção. Trata-se de ressaltar que, na mencionada época, os partidos de oposição do Paraná eram eleitoralmente pouco competitivos. Havia semelhanças entre a forma de envolvimento

\footnotetext{
${ }^{2}$ Acerca da polarização partidária no Distrito Federal no fim dos anos 1910, ver Sá Pinto (2011).
} 
dessas agremiações no jogo eleitoral e a ação política de partidos minoritários criados em outros estados. Uma semelhança consistia na apresentação de chapas incompletas para os cargos do Poder Legislativo. Durante a Primeira República, tal prática era uma estratégia empregada pelos pequenos partidos para evitar a dispersão dos seus votos em candidatos eleitoralmente pouco competitivos (FIGUEIREDO, 2017).

No Paraná, foi apenas em 1890 que uma agremiação minoritária (Partido Operário) apresentou chapa completa (SETE DE MARÇO, 06 set. 1890, p. 4). Em última análise, no início dos anos 1920 o grau de competitividade eleitoral da oposição paranaense permanecia baixo. No referido estado, nos anos finais da Primeira República, não houve mudanças nas estratégias eleitorais dos oposicionistas.

A segunda semelhança entre as agremiações minoritárias do Paraná e dos demais estados brasileiros reside no fato de que os seus candidatos conseguiram mandatos nas épocas em que os governistas apresentaram chapas incompletas. Similarmente ao ocorrido no Paraná, em estados como Rio de Janeiro e Rio Grande do Sul a presença de oposicionistas em esferas do Poder Legislativo era assegurada mediante o lançamento de chapas incompletas pelos seus adversários (FERREIRA, 1994; RIBEIRO, 2019). Portanto, a inserção de partidos minoritários naquelas esferas era uma concessão ocasional das agremiações dominantes. No Paraná, o fim dessa concessão data de 1915 (A REPÚBLICA, 12 out. 1915, p. 1). Em 1923, ao tempo da fundação do PRL, fazia oito anos que os oposicionistas não conseguiam se eleger para cargos públicos.

Por fim, convém fundamentar a terceira constatação desta seção. Trata-se de ressaltar que, no início dos anos 1920, os antigos líderes da oposição paranaense estavam cindidos. Nessa época, eles não se mobilizaram para formar novas agremiações destinadas a combater o PRP. O citado Manuel de Alencar Guimarães, por exemplo, foi cooptado pelos governistas. Por consequência, ele participou das políticas de

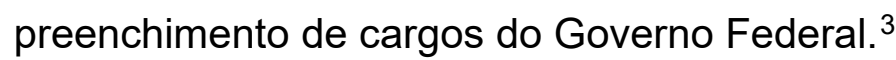

O contexto da criação do PRL foi marcado pela baixa competitividade eleitoral e pela dispersão das lideranças oposicionistas. Tal cenário propiciou a acomodação de novatos em posições centrais do campo da oposição. Os novatos não se conservaram em tais posições por longo tempo. Nos anos 1920, a cena política paranaense diferia daquela existente em estados como Bahia, Rio Grande do Sul e São Paulo. Nesses estados,

\footnotetext{
${ }^{3}$ Nessa época, o cargo mais relevante exercido por Alencar Guimarães foi o de Inspetor Consular para América do Sul e Sul da África (O DIA, 20 ago. 1927, p. 1).
} 
antigos líderes oposicionistas permaneciam unidos para combater de forma reiterada os líderes da situação (ANTONACCI, 1981; BRITO, 2019; PRADO, 1986). Convém, pois, investigar a origem da atividade política dos novatos que se incumbiram da tarefa de reorganizar o campo oposicionista do Paraná.

Ligações familiares, vida profis sional e atividade política dos membros fundadores do PRL

A criação do diretório central do PRL ocorreu na cidade de Curitiba, a capital paranaense, no dia 29 de outubro de 1923 (O DIA, 02 nov. 1923, p. 2). Em tal época, fazia dois anos que a oposição paranaense não estava reunida em uma agremiação. No entanto, a iniciativa de implantar um novo partido não foi chancelada pelos oposicionistas históricos. Ou seja, os indivíduos que haviam comandado agremiações como o Partido Autonomista e o Partido Republicano Federal não se envolveram no projeto de formar o PRL. Trata-se, pois, de analisar os perfis sociais dos responsáveis pela estruturação dessa grei. Para tanto, cumpre dedicar atenção às informações do Quadro 1.

Quadro 1 - Origens das atividades políticas dos integrantes do núcleo dirigente do Partido Republicano Liberal

\begin{tabular}{|c|c|c|c|c|c|c|c|c|}
\hline Nome & $\begin{array}{l}\text { Cargo no } \\
\text { diretório }\end{array}$ & Profissão & $\begin{array}{c}\text { Total de } \\
\text { nomeações } \\
\text { para } \\
\text { cargos } \\
\text { públicos } \\
(1890-1922)\end{array}$ & $\begin{array}{c}\text { Total de } \\
\text { mandatos } \\
\text { eletivos } \\
(1890-1922)\end{array}$ & $\begin{array}{c}\text { Posição } \\
\text { no campo } \\
\text { político } \\
\text { estadual } \\
(1890- \\
1922)\end{array}$ & $\begin{array}{c}\text { Filiação } \\
\text { partidária } \\
(1890-1922)\end{array}$ & $\begin{array}{c}\text { Posição } \\
\text { de } \\
\text { membros } \\
\text { da } \\
\text { parentela } \\
\text { no campo } \\
\text { político } \\
\text { estadual } \\
(1890- \\
1922) \\
\end{array}$ & $\begin{array}{c}\text { Filiação } \\
\text { partidária de } \\
\text { membros da } \\
\text { parentela } \\
(1890-1922)\end{array}$ \\
\hline $\begin{array}{c}\text { Flávio } \\
\text { Ferreira } \\
\text { da Luz }\end{array}$ & $\begin{array}{c}\text { President } \\
\mathrm{e}\end{array}$ & Advogado & 0 & 0 & - & - & Situação & $\begin{array}{c}\text { Partido } \\
\text { Republicano } \\
\text { Paranaense }\end{array}$ \\
\hline $\begin{array}{c}\text { Antônio } \\
\text { Sérgio } \\
\text { Virgulino } \\
\text { Brasil }\end{array}$ & $\begin{array}{c}\text { Vice- } \\
\text { president } \\
\mathrm{e}\end{array}$ & $\begin{array}{c}\text { Cirurgião- } \\
\text { dentista/ } \\
\text { Professor do } \\
\text { ensino superior }\end{array}$ & 0 & 0 & - & - & - & - \\
\hline Ciro Silva & $\begin{array}{c}\text { Secretário } \\
\text {-Geral }\end{array}$ & $\begin{array}{l}\text { Advogado } \\
\text { solicitador/ } \\
\text { Professor do } \\
\text { ensino técnico }\end{array}$ & 0 & 0 & - & - & $\begin{array}{l}\text { Situação/ } \\
\text { Oposição }\end{array}$ & $\begin{array}{c}\text { Partido } \\
\text { Republicano } \\
\text { Paranaense/P } \\
\text { artido } \\
\text { Republicano } \\
\text { Conservador }\end{array}$ \\
\hline $\begin{array}{c}\text { Alceu } \\
\text { Chichorro }\end{array}$ & $\begin{array}{l}\text { Membro } \\
\text { efetivo }\end{array}$ & Jornalista & 0 & 0 & - & - & $\begin{array}{l}\text { Situação/ } \\
\text { Oposição }\end{array}$ & $\begin{array}{c}\text { Partido } \\
\text { Republicano } \\
\text { Paranaense/P } \\
\text { artido } \\
\text { Republicano } \\
\text { Conservador }\end{array}$ \\
\hline $\begin{array}{l}\text { Diógenes } \\
\text { Brasil } \\
\text { Lobato }\end{array}$ & $\begin{array}{l}\text { Membro } \\
\text { efetivo }\end{array}$ & $\begin{array}{c}\text { Advogado } \\
\text { /Professor do } \\
\text { ensino básico }\end{array}$ & 1 & 1 & Situação & $\begin{array}{c}\text { Partido } \\
\text { Republicano } \\
\text { Paranaense }\end{array}$ & - & - \\
\hline $\begin{array}{c}\text { Euclides } \\
\text { Rocha }\end{array}$ & $\begin{array}{l}\text { Membro } \\
\text { efetivo }\end{array}$ & Advogado & 0 & 0 & - & - & - & - \\
\hline
\end{tabular}




\begin{tabular}{|c|c|c|c|c|c|c|c|c|}
\hline Nome & $\begin{array}{l}\text { Cargo no } \\
\text { diretório }\end{array}$ & Profissão & $\begin{array}{c}\text { Total de } \\
\text { nomeações } \\
\text { para cargos } \\
\text { públicos } \\
(1890-1922)\end{array}$ & $\begin{array}{c}\text { Total de } \\
\text { mandatos } \\
\text { eletivos } \\
(1890- \\
1922)\end{array}$ & $\begin{array}{c}\text { Posição } \\
\text { no campo } \\
\text { político } \\
\text { estadual } \\
\text { (1890- } \\
1922)\end{array}$ & $\begin{array}{c}\text { Filiação } \\
\text { partidária } \\
(1890-1922)\end{array}$ & $\begin{array}{c}\text { Posição } \\
\text { de } \\
\text { membros } \\
\text { da } \\
\text { parentela } \\
\text { no campo } \\
\text { político } \\
\text { estadual } \\
(1890- \\
1922) \\
\end{array}$ & $\begin{array}{c}\text { Filiação } \\
\text { partidária de } \\
\text { membros da } \\
\text { parentela } \\
(1890-1922)\end{array}$ \\
\hline $\begin{array}{c}\text { Francisco } \\
\text { das } \\
\text { Chagas } \\
\text { Lopes }\end{array}$ & $\begin{array}{c}\text { Membro } \\
\text { efetivo }\end{array}$ & Empresário & 0 & 0 & - & - & - & - \\
\hline $\begin{array}{c}\text { Ildefonso } \\
\text { Pereira } \\
\text { Correia }\end{array}$ & $\begin{array}{c}\text { Membro } \\
\text { efetivo }\end{array}$ & Jornalista & 0 & 0 & - & - & Situação & $\begin{array}{c}\text { Partido } \\
\text { Republicano } \\
\text { Paranaense/Par } \\
\text { tido } \\
\text { Republicano } \\
\text { Federal } \\
\end{array}$ \\
\hline $\begin{array}{c}\text { João } \\
\text { Mariano } \\
\text { Ferreira }\end{array}$ & $\begin{array}{c}\text { Membro } \\
\text { efetivo }\end{array}$ & Empresário & 0 & 0 & - & - & - & - \\
\hline $\begin{array}{c}\text { Luís } \\
\text { Napoleão } \\
\text { Lopes }\end{array}$ & $\begin{array}{c}\text { Membro } \\
\text { efetivo }\end{array}$ & $\begin{array}{c}\text { Advogado/ } \\
\text { Jornalista }\end{array}$ & 0 & 0 & Oposição & $\begin{array}{c}\text { Partido } \\
\text { Republicano } \\
\text { Conservador }\end{array}$ & - & - \\
\hline
\end{tabular}

Fontes: A Notícia (PR); A República (PR); Diário da Tarde (PR); Diário do Comércio (PR); O Dia (PR)

As informações presentes nesse Quadro possibilitam a fundamentação de três afirmações. A primeira afirmação salienta que uma pequena parte dos fundadores da grei já havia cultivado ligações com partidos. Todavia, essas ligações não foram acompanhas pela conquista de posições relevantes no quadro político. Por consequência, compete identificar a natureza da participação de fundadores do PRL na vida partidária paranaense nos anos anteriores ao surgimento dessa agremiação.

O dirigente dessa grei que possuía maior experiência na cena partidária era Diógenes Lobato. Ele pertenceu ao rol dos governistas cujo principal benefício decorrente do envolvimento com o partido dominante consistiu na obtenção de nomeações para cargos públicos. No entanto, Lobato fez parte do conjunto de situacionistas que não conquistaram nomeações para postos centrais da administração pública. Assim, o PRL contava com a participação de um indivíduo que ocupou posição subalterna no quadro dos correligionários da grei situacionista.

A esse respeito, cumpre mencionar que, no ano de 1898, Lobato se tornou servidor público estadual. Nessa ocasião, ele foi nomeado pelo governador do Paraná para o posto de professor do ensino primário de Campo Largo, cidade adstrita a Curitiba (A REPÚBLICA, 02 jul. 1898, p. 1). No início dos anos 1900, Lobato se transferiu para 
Araucária, município adjacente à capital. Em meados dessa década, tal professor já estava vinculado ao PRP. Nesse contexto, ele desempenhou mandato de vereador em Araucária (A REPÚBLICA, 15 jan. 1907, p. 2). O limite da ascensão política de Lobato consistiu no exercício do cargo de vereador em um pequeno município do primeiro planalto do Paraná. Ele pertenceu à categoria dos governistas que não tiveram os seus nomes incluídos de forma reiterada em chapas de candidatos, bem como não comandaram os diretórios locais do PRP.

No início da década de 1920, Lobato atuava como advogado em comarcas do primeiro planalto (A REPÚBLICA, 23 mar. 1921, p. 2). No contexto correspondente aos anos anteriores à fundação do $\mathrm{PRL}$, não há evidências do vínculo de tal indivíduo a uma agremiação. De todo modo, as informações atinentes a esse egresso do governismo permitem salientar uma aproximação entre o PRL e os partidos de oposição que o antecederam no Paraná. Essa aproximação reside no fato de que tais agremiações conseguiram o apoio de indivíduos que viviam em pequenos municípios e não tiveram decisivas oportunidades políticas ao tempo em que integraram o partido dominante.

Uma fração dos correligionários desses partidos era constituída por indivíduos cujo principal envolvimento na cena política consistiu em organizar localmente as campanhas do PRP. Portanto, a adesão a uma grei oposicionista era uma oportunidade para a retomada da atividade política dos integrantes dessa parcela de correligionários. ${ }^{4}$

No núcleo dirigente do PRL, o indivíduo dotado de maior experiência política estava sem exercer um mandato havia quinze anos. Lobato, em suma, tivera a sua trajetória marcada por atuação episódica no jogo eleitoral. A presença no diretório central de uma agremiação minoritária representou o principal momento de sua influência sobre a vida interna de um partido.

Trata-se, pois, de atentar ao caso do outro fundador do PRL que possuía experiência prévia nas lides partidárias. Tal indivíduo era o advogado Luís Napoleão Lopes. O princípio de suas atividades políticas data de 1915. Nesse ano, ele se filiou ao Partido Republicano Conservador e disputou uma vaga no Congresso Legislativo do Paraná. Lopes não teve sucesso nessa eleição (A REPÚBLICA, 31 jan. 1916, p. 1).

\footnotetext{
${ }^{4}$ Em 1919, ao tempo de sua fundação, o Partido Autonomista teve a adesão de indivíduos residentes em municípios distantes da capital paranaense (A REPÚBLICA, 03 out. 1919, p. 2). Em 1915, as campanhas eleitorais realizadas pelo Partido Republicano Conservador no Paraná também contaram com a colaboração de correligionários que viviam no interior e provinham do situacionismo (ANAIS DA CÂMARA DOS DEPUTADOS, 1916, v. 2, p. 809).
} 
Contrariamente a Lobato, Lopes iniciou-se na vida partidária do Paraná na condição de opositor do PRP. No fim dos anos 1910, ele permaneceu envolvido na vida partidária. Mais precisamente, no ano de 1919 Lopes pertenceu ao citado Partido Autonomista. Porém, ele não foi integrado às chapas apresentadas por essa agremiação ( $A$ REPÚBLICA, 03 out. 1919, p. 1). Portanto, no mencionado decênio Lopes não alcançou uma posição de liderança nos partidos minoritários do Paraná.

A aproximação entre Lobato e Lopes reside no fato de que, na época da criação do $\mathrm{PRL}$, eles estavam afastados da vida partidária. Os veteranos integrados à diretoria dessa grei eram indivíduos distinguidos por uma atividade política intermitente. Nos anos anteriores ao surgimento desse partido, os referidos indivíduos não cultivaram sólidos vínculos com os chefes locais da situação ou da oposição.

Compete, pois, de fundamentar a segunda constatação desta seção. Essa constatação assinala que uma parte dos novatos do PRL possuía relações de parentesco com políticos que vivenciaram o declínio de sua influência na vida partidária no decorrer das décadas de 1900 e 1910. Mais precisamente, cumpre evidenciar que uma parcela dos gestores do PRL tinha ligações familiares com indivíduos que não conseguiram se conservar em posições de destaque tanto no campo da oposição quanto no campo da situação.

Cabe ressaltar, inicialmente, o caso do escritor Ildefonso Pereira Correia (18881949). Ele era filho de um negociante homônimo que, no contexto da passagem do Império para a República, era o principal exportador de erva-mate do Paraná (COSTA, 1981). Ao tempo do Segundo Reinado, a família Correia exerceu marcante interferência sobre a vida interna do Partido Conservador paranaense (ALVES, 2014). No início da Primeira República, os seus membros estavam integrados ao partido governista do estado (A REPÚBLICA, 06 nov. 1896, p. 1). Em suma, Ildefonso Correia pertenceu a uma parentela distinguida pela conjunção entre poder econômico e poder político.

Todavia, nas primeiras décadas do século $X X$ os integrantes dessa família perderam espaço na vida econômica e política paranaense. Ildefonso Correia tentou, sem sucesso, atuar como empresário. ${ }^{5}$ Em seguida, voltou-se à carreira literária. A atuação como escritor lhe permitiu estabelecer contato com futuros integrantes do PRL que

\footnotetext{
${ }^{5}$ No início dos anos 1910, Ildefonso Correia e seu primo Adalberto Nácar Correia foram sócios em uma empresa de cinematógrafo na cidade de Curitiba. A sociedade foi dissolvida em 1913 (A REPÚBLICA, 14 fev. 1913, p. 3).
} 
também se dedicaram à literatura. Esses integrantes eram Alceu Chichorro (1896-1977) e Ciro Silva (1881-1968) (IORIO, 2004).

Compete também salientar que, quando ocorreu a implantação do PRL, Ildefonso Correia fazia parte de um círculo social composto por outro membro fundador da grei. Tal membro era Francisco das Chagas Lopes. Em 1888, o pai de Ildefonso Correia associouse a Lopes para atuar no ramo das artes gráficas. ${ }^{6}$ Desse modo, há evidências de que no começo dos anos 1920 uma parte das famílias dos fundadores do PRL já cultivavam antigas relações entre si. Em boa medida, essas relações foram consolidadas pelo fato de que elas pertenciam aos mesmos círculos profissionais e culturais.

De outra parte, cabe mencionar que, nos decênios de 1900 e 1910, um dos tios paternos de Ildefonso Correia tentou se consolidar como uma liderança da oposição estadual. Porém, ele não teve êxito nessa tarefa. ${ }^{7}$ Em resumo, quando houve a criação do PRL a família de Ildefonso Correia era marcada por experiências malogradas na vida empresarial e política paranaense.

Alceu Chichorro, Ciro Silva e Flávio Luz também provinham de famílias que perderam espaço na cena partidária paranaense. Ao tempo da criação do PRL, essas parentelas estavam politicamente enfraquecidas. O pai de Alceu Chichorro era o funcionário público Joaquim Procópio, um egresso do PRP. Esse servidor teve breve passagem pelo campo oposicionista. Em 1915, ele não conseguiu se eleger deputado estadual na chapa do Partido Republicano Conservador (A REPÚBLICA, 31 jan. 1916, p. 1).

Ciro Silva, por sua vez, era irmão do engenheiro civil José Niepce da Silva (18761935). Ele, José Niepce, era um governista dissidente que pertenceu ao Partido Republicano Conservador nos anos 1910 (DIÁRIO DA TARDE, 06 nov. 1915, p. 1). Porém, nos anos 1920 tal engenheiro não se filiou a partidos (O DIA, 25 mar. 1927, p. 1).

Por fim, Flávio Ferreira era sobrinho pelo lado paterno do ex-senador Brasílio Ferreira da Luz (1857-1940). No início dos anos 1920, havia membros dessa parentela que permaneciam como apoiadores dos próceres da situação. Nessa época, porém, tais

\footnotetext{
${ }^{6}$ Essa parceria originou uma empresa denominada Impressora Paranaense. Francisco Lopes exerceu o posto de gerente dessa empresa (CARNEIRO, 1976). Cabe mencionar que Lopes era neto de Cândido Martins Lopes, o fundador do primeiro jornal do Paraná, o Dezenove de Dezembro, em 1854 (NEGRÃO, 2004 , v. 2, p. 267).

7 Tal indivíduo era o jornalista Leôncio Correia (1865-1950). Nos decênios de 1900 e 1910, ele experimentou sucessivas derrotas eleitorais. A sua última campanha eleitoral foi para o cargo de deputado federal, em 1918. Nessa ocasião, obteve a última colocação no pleito (ANAIS DA CÂMARA DOS DEPUTADOS, v. 1, 1919, p. 85-86).
} 
membros não desempenharam funções relevantes nos quadros do PRP (A REPÚBLICA, 09 set. 1921, p. 1).

A criação do PRL não promoveu a aliança política entre membros de parentelas que pertenciam à cena partidária regional. Os integrantes dessas famílias continuaram a adotar movimentos independentes em tal cena. Eles não atuaram juntos nos projetos de instauração de novos partidos oposicionistas. No período em tela, os componentes dessas parentelas permaneceram politicamente apartados.

Compete, pois, sustentar a terceira afirmação desta seção. Tal afirmação reconhece que os principais mentores da criação do PRL foram indivíduos desprovidos de vínculos prévios com os partidos estaduais. Eles também não possuíam estreitas ligações sociais com indivíduos que pertenceram a essas agremiações. As informações do Quadro 1 demonstram que a camada majoritária desses fundadores era composta por profissionais autônomos que não tiveram passagens por esferas da administração pública. Em resumo, eles estavam afastados dos esquemas de preenchimento de cargos públicos.

O quadro de gestores do PRL contou com a presença de integrantes do meio universitário de Curitiba. O vice-presidente do partido, Virgulino Brasil, era professor catedrático da Universidade do Paraná. Ele lecionava no curso de Odontologia (NEGRÃO, 2004, v. 1, p. 417). Ciro Silva, por sua vez, era estudante quando participou da formação do PRL. Ele ocupou o posto de secretário-geral da agremiação. Ao tempo da criação desse partido, Silva estava matriculado no quinto ano do curso de Direito da referida universidade. Porém, atuava como advogado solicitador desde o ano anterior (A REPÚBLICA, 11 mar. 1922, p. 1). Em virtude de sua condição de membro do Centro de Letras do Paraná, Silva também integrava um círculo social constituído por jornalistas e literatos da capital (O DIA, 29 mar. 1924, p. 4).

De outra parte, os indivíduos mencionados no Quadro 1 como empresários não pertenciam ao rol dos negociantes que tinham acesso a instituições como a Associação Comercial do Paraná. No período em tela, tal entidade congregava a elite empresarial do estado.

O PRL promoveu, ainda que provisoriamente, a coesão entre membros de antigas famílias da elite local e novos personagens do meio universitário, da cena literária e da vida empresarial da capital paranaense. Uma diferença entre o PRL e a maior parte das agremiações oposicionistas que a precederam reside na disposição para sustentar um ideário programático. Compete, assim, evidenciar as principais propostas advogadas pelos dirigentes desse partido. 


\section{O tema das reformas política, econômica e social: o repertório de propostas do PRL}

A fundação do PRL foi marcada pela divulgação de um conjunto de propostas políticas e sociais. A formulação de sugestões programáticas diferenciou o PRL da maior parte das agremiações oposicionistas do Paraná da Primeira República. Tais agremiações não se dedicaram a conceber um minucioso ideário. O Partido Operário, cuja criação data de 1890, e o PRL surgiram como as exceções na cena política regional. Ou seja, desde a criação do Partido Operário transcorreram três décadas até o aparecimento de outra agremiação paranaense (PRL) distinguida pela sustentação de um projeto político. ${ }^{8}$

O Programa do Partido Republicano Liberal é constituído por vinte e três artigos. Nesse documento são abordados assuntos econômicos, políticos e sociais. No plano político, os dirigentes da agremiação defendiam que os partidos minoritários deveriam ter espaço cativo nas instâncias do Poder Legislativo. Para tanto, advogavam que às agremiações dominantes deveria ser vedada a apresentação de chapas completas. Tal ideia está contida no décimo quinto Artigo do Programa: "O Partido Republicano Liberal é pela representação das minorias, assegurada ela pela abstenção completa e absoluta da maioria em pleiteá-la" (O DIA, 02 nov. 1923, p. 7).

Desse modo, o partido defendia que era necessário pôr fim à situação em que a presença das oposições em instituições políticas era apenas uma concessão ocasional dos governistas. Nesse âmbito, o PRL reivindicava a obrigatoriedade do lançamento de chapas incompletas pelos partidos majoritários.

Essa agremiação era partidária da Reforma Eleitoral. No décimo terceiro Artigo do Programa do PRL, lê-se a seguinte afirmação: "O Partido Republicano Liberal é pelo voto secreto" (O DIA, 02 nov. 1923, p. 7). Nessa época, tal ideia não possuía unânime adesão das elites regionais que se opunham ao predomínio de Minas Gerais e São Paulo na vida política nacional (FERREIRA, 1993). Essa proposta se tornou consensual entre as lideranças oposicionistas somente nos anos finais da Primeira República (PRADO, 1986).

Quanto aos assuntos econômicos, o PRL pugnava pela reforma tributária. Mais especificamente, os dirigentes da grei recomendavam a simplificação das formas de cobrança de tributos. Eles também salientavam a pertinência da redução do valor dos

\footnotetext{
8 De fato, os partidos nacionais existentes nos anos 1910 possuíam um pequeno conjunto de propostas. Uma das propostas do Partido Republicano Conservador era a realização de mudanças na legislação tributária. De sua parte, o Partido Republicano Liberal advogava a revisão constitucional. Todavia, essas
} 
impostos. Tais dirigentes eram favoráveis à implantação do imposto único. Contudo, reconheciam as dificuldades de instituir uma medida dessa natureza. No décimo primeiro Artigo do PRL, encontra-se a defesa de um "[...] sistema tributário equitativo e mais geral, menos confuso em suas origens federal, estadual e municipal” (O DIA, 02 nov. 1923, p. 7).

Nota-se, assim, que os próceres do PRL se apresentavam como defensores de demandas do empresariado paranaense acerca de mudanças na política tributária. Desde o início da Primeira República, as principais reivindicações da Associação Comercial do Paraná diziam respeito à extinção e à redução do valor de tributos (A REPÚBLICA, 17 jan. 1896, p. 2). ${ }^{9}$

Cumpre mencionar, por fim, que o Programa do PRL também dedicou atenção à questão social. Os gestores da grei reconheceram os problemas decorrentes da desigualdade econômica. Entretanto, eles não formularam propostas dirigidas exclusivamente aos trabalhadores de modesta condição social. Os próceres do PRL afirmaram que a categoria de operário poderia ser alusiva a profissionais dedicados a diferentes misteres e pertencentes a qualquer estrato social.

A esse respeito, convém transcrever a seguinte passagem do sexto Artigo do mencionado Programa: “'[...] todos os indivíduos devem ser considerados operários, a todos cabendo direitos e deveres, sendo função da Política impedir que o Capital, em vez de ser um fator de felicidade geral, se torne elemento de separações e desigualdades" (O DIA, 02 nov. 1923, p. 7). No entendimento dos gestores do PRL, era preciso evitar que essas desigualdades transformassem a "hierarquia natural em fonte de incompatibilidades injustificáveis e absurdas" (O DIA, 02 nov. 1923, p. 7).

A proposta mais avançada do PRL consistia na defesa do voto secreto. Mais amplamente, nota-se que os fundadores da grei haviam aderido à ideia da Reforma Eleitoral. De outra parte, eles reconheciam a necessidade de formular propostas respeitantes aos problemas sociais. Porém, não situavam as demandas do movimento operário como elementos centrais do seu Programa. Os dirigentes do partido também endossaram reivindicações do empresariado. Em síntese, eles não defendiam profundas mudanças sociais. Ao contrário, consideravam que a sociedade possuía divisões inarredáveis.

propostas não foram divulgadas nas campanhas eleitorais empreendidas pelos líderes paranaenses dessas agremiações. Acerca das ideias sustentadas por ambos os partidos, ver Chacon (1985).

9 Concernente à natureza da política tributária adotada pelo Governo do Paraná durante a Primeira República, ver Cassol (1973). 


\section{O desempenho do PRL na eleição parlamentar de 1924}

O PRL participou de apenas uma campanha eleitoral. A agremiação lançou um candidato a deputado federal em um pleito ocorrido no dia 17 de fevereiro de 1924. Esse partido não rompeu com a antiga prática das agremiações minoritárias de homologar apenas uma candidatura em eleições para a Câmara dos Deputados. O PRL buscou conquistar uma representação mínima em tal instituição. O candidato escolhido foi o citado Luís Napoleão Lopes. Conforme acima ressaltado, ele possuía experiência em participar de campanha eleitoral como membro de partido minoritário. Para a análise do desempenho do postulante do PRL nesse pleito, cumpre analisar as informações expostas na Tabela 1.

Tabela 1 - Resultado da eleição para deputado federal no Estado do Paraná (1924)

\begin{tabular}{|c|c|c|c|c|c|c|}
\hline $\begin{array}{l}\text { Nome do } \\
\text { candidato }\end{array}$ & Profissão & Partido & $\begin{array}{l}\text { Posição no } \\
\text { campo } \\
\text { político }\end{array}$ & $\begin{array}{c}\text { Votação do } \\
\text { candidato (em } \\
\text { números } \\
\text { absolutos) }\end{array}$ & $\begin{array}{l}\text { Percentual da } \\
\text { votação do } \\
\text { candidato }\end{array}$ & Resultado \\
\hline Eurides Cunha & Advogado & $\begin{array}{c}\text { Partido } \\
\text { Republicano } \\
\text { Paranaense }\end{array}$ & Situação & 10.279 & 25,1 & Eleito \\
\hline $\begin{array}{l}\text { Arthur Martins } \\
\text { Franco }\end{array}$ & Engenheiro Civil & $\begin{array}{c}\text { Partido } \\
\text { Republicano } \\
\text { Paranaense }\end{array}$ & Situação & 10.237 & 25 & Eleito \\
\hline Plínio Marques & Médico & $\begin{array}{c}\text { Partido } \\
\text { Republicano } \\
\text { Paranaense } \\
\end{array}$ & Situação & 10.163 & 24,9 & Eleito \\
\hline Lindolfo Pessoa & Advogado & $\begin{array}{c}\text { Partido } \\
\text { Republicano } \\
\text { Paranaense } \\
\end{array}$ & Situação & 10.148 & 24,7 & Eleito \\
\hline $\begin{array}{l}\text { Luís Napoleão } \\
\text { Lopes }\end{array}$ & Advogado & $\begin{array}{c}\text { Partido } \\
\text { Republicano } \\
\text { Liberal }\end{array}$ & Oposição & 135 & 0,3 & Não eleito \\
\hline
\end{tabular}

Fonte: Anais da Câmara dos Deputados (1929, v. 1, p. 109).

Respeitante à participação do $\mathrm{PRL}$ nessa disputa, cumpre sustentar três afirmações. Primeiro, cabe ressaltar que a votação angariada pelo candidato do PRL nessa ocasião foi pouco expressiva. Nesse contexto, permanecia muito estável o domínio do PRP sobre o jogo eleitoral do estado.

O PRL teve a menor votação dentre os partidos minoritários que disputaram eleições para a Câmara dos Deputados no Paraná na época da Primeira República. $\mathrm{O}$ surgimento dessa agremiação não promoveu uma reaproximação entre os oposicionistas históricos do estado. $O$ aparecimento de tal partido também não contribuiu para conservar a base eleitoral da oposição. No período em tela, os contendores do governismo permaneciam desarticulados. Para atestar essas informações, compete destacar que o 
candidato apresentado pelo Partido Autonomista em 1921 angariou 2.700 sufrágios, os quais representaram $6 \%$ do total de votos (GAZETA DE NOTÍCIAS, 02 mar. 1921, p. 2). Assim, de 1921 a 1924 notou-se a diminuição do rol de apoiadores da oposição.

A segunda constatação salienta que os dirigentes do PRL não cogitavam disputar a eleição de deputado federal em 1924. Nesse contexto, Napoleão Lopes apresentou-se como postulante independente. Foi tardia a adesão do partido à candidatura desse correligionário. Esse apoio foi formalizado duas semanas antes do pleito, em uma reunião datada de 3 de fevereiro de 1924 (O DIA, 06 fev. 1924, p. 5).

Em última análise, o PRL não formulou um consistente plano para divulgar a candidatura de Lopes. Nessa época, tal agremiação não estava suficientemente organizada para enfrentar a chapa completa dos situacionistas. Ciro Silva reconheceu que o partido não tinha a força necessária para eleger Lopes. Porém, o apoio a esse advogado era um protesto contra a recusa do PRP em ceder à minoria uma vaga na Câmara dos Deputados (O DIA, 16 fev. 1924, p. 4).

A terceira constatação afirma que o PRL foi um partido que não conseguiu numerosos apoios para além da capital do estado. A adesão de governistas dissidentes em cidades próximas a Curitiba consistiu no limite do recrutamento de correligionários deflagrado pela agremiação. Existem indícios de que esse partido possuía apenas um diretório. A homologação da candidatura de Lopes, por exemplo, foi uma decisão chancelada unicamente por correligionários residentes na capital (O DIA, 05 fev. 1924, p. 6). Assim, é factível considerar que o PRL foi extinto sem realizar o objetivo de instituir diretórios locais. Tal objetivo constava no Programa da grei (O DIA, 02 nov. 1923, p. 7).

As atividades do PRL foram encerradas após o término da mencionada eleição. Portanto, a duração dessa grei foi inferior a quatro meses. Esse partido teve a menor duração dentre as agremiações minoritárias criadas no Paraná da Primeira República. Trata-se, pois, de investigar os destinos dos fundadores desse partido nos anos seguintes à dissolução da grei.

\section{Os destinos políticos dos membros fundadores do PRL}

O fim da campanha eleitoral de 1924 ocasionou a redução da atividade política dos próceres do PRL. Após a extinção dessa grei, permaneceu pouco relevante o envolvimento desses dirigentes na cena partidária paranaense. A análise de tal envolvimento demanda, 
preliminarmente, uma contextualização da vida política regional no período correspondente aos anos finais da Primeira República e ao limiar da Era Vargas.

No fim dos anos 1920, a oposição estadual se reorganizou. De 1926 a 1927, esteve em funcionamento uma agremiação oposicionista denominada Partido Democrático. Após a extinção dessa grei, uma parcela dos seus dirigentes criou o diretório regional da Aliança Liberal, a qual sustentou a candidatura presidencial de Getúlio Vargas em 1930. Esses dirigentes eram políticos veteranos que estavam sem exercer mandatos desde os anos 1910 (GOULART, 2014).

Nessa época, houve uma recuperação da força eleitoral da oposição paranaense. Na eleição de deputado federal acontecida em 1927, o candidato do Partido Democrático angariou 6.517 votos (13,2\%) (O DIA, 30 mar. 1927, p. 1). Em 1930, os três candidatos da Aliança Liberal a tal cargo auferiram, juntos, 27.957 sufrágios (16,8\%) (O DIA, 10 abr. 1930 , p. 1). Os postulantes de ambos os partidos não conseguiram se eleger. Todavia, os percentuais de votos que alcançaram denotam que, em relação à época de funcionamento do PRL, os oposicionistas estavam eleitoralmente mais fortalecidos.

No Paraná, no período que abarca os anos de 1931 a 1937, houve crescimento do número de partidos (RICCI, 2019). Denominada Partido Social Democrático, a agremiação situacionista possuía o maior número de mandatários (DIÁRIO DA TARDE, 25 set. 1937, p. 2). Nesse contexto, antigas lideranças políticas da época da Primeira República conseguiram retornar à cena partidária regional. Essas lideranças também se envolveram nos esquemas de nomeações para cargos públicos comandados localmente pelo interventor Manuel Ribas (DAGOSTIM, 2011). O estudo dos movimentos dos remanescentes do PRL nesse novo momento político exige a análise das informações do Quadro 2. 
Quadro 2 - Desfecho das atividades políticas dos integrantes do núcleo dirigente do Partido Republicano Liberal

\begin{tabular}{|c|c|c|c|c|c|c|c|}
\hline Nome & Profissão & $\begin{array}{c}\text { Total de } \\
\text { nomeações } \\
\text { para cargos } \\
\text { públicos }\end{array}$ & $\begin{array}{c}\text { Total de } \\
\text { mandatos } \\
\text { eletivos } \\
(1924-1937)\end{array}$ & $\begin{array}{c}\text { Posição no } \\
\text { campo político } \\
\text { estadual (1924- } \\
\text { 1937) }\end{array}$ & $\begin{array}{c}\text { Filiação } \\
\text { partidária } \\
(1924-1937)\end{array}$ & $\begin{array}{c}\text { Posição } \\
\text { de } \\
\text { membros } \\
\text { da } \\
\text { parentela } \\
\text { no } \\
\text { campo } \\
\text { político } \\
\text { estadual } \\
\text { (1924- } \\
1937)\end{array}$ & $\begin{array}{c}\text { Filiação } \\
\text { partidária de } \\
\text { membros da } \\
\text { parentela }\end{array}$ \\
\hline $\begin{array}{c}\text { Alceu } \\
\text { Chichorro }\end{array}$ & Jornalista & 1 & 0 & - & - & Situação & $\begin{array}{c}\text { Partido } \\
\text { Social } \\
\text { Democrático }\end{array}$ \\
\hline $\begin{array}{c}\text { Antônio } \\
\text { Sérgio } \\
\text { Virgulino } \\
\text { Brasil }\end{array}$ & $\begin{array}{c}\text { Cirurgião- } \\
\text { dentista/Professor } \\
\text { do ensino superior }\end{array}$ & 1 & 0 & Situação & - & - & - \\
\hline Ciro Silva & $\begin{array}{l}\text { Advogado/Professor } \\
\text { do ensino técnico }\end{array}$ & 0 & 1 & Oposição & $\begin{array}{l}\text { Partido Social } \\
\text { Nacionalista }\end{array}$ & - & - \\
\hline $\begin{array}{c}\text { Diógenes } \\
\text { Brasil Lobato }\end{array}$ & Advogado & 0 & 0 & - & - & - & - \\
\hline $\begin{array}{l}\text { Euclides } \\
\text { Rocha }\end{array}$ & Advogado & 0 & 0 & - & - & - & - \\
\hline $\begin{array}{c}\text { Flávio Ferreira } \\
\text { da Luz }\end{array}$ & Advogado & 0 & 0 & - & - & - & - \\
\hline $\begin{array}{l}\text { Francisco das } \\
\text { Chagas Lopes }\end{array}$ & Empresário & 0 & 0 & - & - & - & - \\
\hline $\begin{array}{l}\text { Ildefonso } \\
\text { Pereira } \\
\text { Correia }\end{array}$ & $\begin{array}{l}\text { Servidor público } \\
\text { federal }\end{array}$ & 0 & 0 & Situação & - & - & - \\
\hline $\begin{array}{l}\text { João Mariano } \\
\text { Ferreira }\end{array}$ & Empresário & 0 & 0 & - & - & - & - \\
\hline $\begin{array}{l}\text { Luís Napoleão } \\
\text { Lopes }\end{array}$ & $\begin{array}{l}\text { Advogado/ } \\
\text { Jornalista }\end{array}$ & 0 & 0 & - & - & - & - \\
\hline
\end{tabular}

Fontes: A República (PR); Correio do Paraná (PR); Diário da Tarde (PR); Diário do Comércio (PR); O Dia (PR)

As informações inseridas nesse Quadro possibilitam a fundamentação de duas afirmações. Primeiro, cabe salientar que uma pequena parte dos remanescentes do PRL manteve atividade política após o fim dessa grei. Essa atividade data do início dos anos 1930. A principal consequência do envolvimento de tais indivíduos com membros da ordem política situacionista instaurada no Paraná nesse decênio consistiu no ingresso no serviço público. Porém, esse ingresso não lhes propiciou a conquista de posições centrais nos órgãos do Governo do Estado.

No começo da mencionada década, Virgulino Brasil foi nomeado dentista do Corpo de Bombeiros (O DIA, 19 mar. 1931, p. 5). Ildefonso Correia, por sua vez, migrou para a cidade de São Paulo. Nesse município, exerceu o posto de inspetor federal de ensino (DIÁRIO DA TARDE, 02 jul. 1949, p. 1). A obtenção de nomeações para cargos públicos não foi acompanhada pela filiação de tais indivíduos a um partido situacionista. Porém, 
essa obtenção evidencia que eles possuíam as conexões políticas necessárias para serem incorporados aos esquemas de preenchimentos de cargos estaduais e federais.

Ao mesmo tempo, cabe salientar que Napoleão Lopes, no início dos anos 1930, também se transferiu para a cidade de São Paulo. Ali, atuou como jornalista (O DIA, 01 mar. 1931, p. 2). Desse modo, no princípio da Era Vargas o grupo de dirigentes do PRL continuava politicamente desarticulado. Em sua maior parte, os fundadores da grei que permaneceram residentes em Curitiba não mantiveram vínculo formal com uma agremiação. Eles também não obtiveram oportunidades de atuar em instâncias da administração pública.

Ciro Silva foi o único egresso do PRL que se integrou à vida partidária dos anos 1930 e conseguiu um mandato eletivo. De 1935 a 1937, ele foi vereador à Câmara de Curitiba. Silva pertenceu à bancada do Partido Social Nacionalista (PSN), uma agremiação oposicionista (O DIA, 28 fev. 1937, p. 1). Portanto, esse bacharel se manteve refratário ao vínculo com situacionistas. Por outro lado, ele não recuperou a posição de protagonismo que teve no campo oposicionista no biênio 1923-1924. Silva se acomodou na condição de um político cuja projeção era limitada ao âmbito municipal. Ao mesmo tempo, ele não desempenhou funções capitais na vida interna da agremiação à qual se filiou. O PSN era comandado por militares, bem como por políticos veteranos que tiveram ligações com o partido dominante do Paraná da época da Primeira República (OLIVEIRA, 1997).

De fato, no período em tela uma parcela dos egressos do PRL se manteve unida. Essa proximidade era decorrente do envolvimento em atividades literárias. Ciro Silva e Alceu Chichorro, por exemplo, eram confrades no Centro de Letras do Paraná (O DIA, 21 mai. 1935, p. 3). Contrariamente a Silva, em tal contexto Chichorro se dedicava exclusivamente ao jornalismo (BOIA, 1998). Em suma, uma parte dos fundadores do PRL desenvolveu vínculos sociais mais duradouros na vida literária do que nas lides políticas.

\section{Considerações finais}

O presente artigo investigou os processos de formação e dissolução de uma agremiação minoritária que existiu no Estado do Paraná, no começo dos anos 1920. Por meio de um estudo de caso, buscou-se avançar na compreensão acerca da organização interna e da ação eleitoral dos partidos de oposição que existiram no Brasil no decorrer da Primeira República. Cumpre, pois, destacar três resultados apresentados no curso deste trabalho. 
Primeiro, cabe ressaltar que o PRL era dirigido majoritariamente por novatos da cena política paranaense. Essa agremiação não obteve expressivas adesões para além da capital do estado. Por consequência, o partido não conseguiu deflagrar um projeto de expansão de diretórios. Ele também não teve êxito na tarefa de formar uma base eleitoral. Verifica-se, pois, que os novatos malograram na tarefa de contrabalançar o predomínio que a agremiação oficial exercia na vida eleitoral do estado. Em boa medida, esse malogro decorreu do fato de que os novatos não reorganizaram o campo oposicionista. Os antigos e os novos contendores do governismo permaneceram politicamente desarticulados.

A segunda constatação salienta que o PRL foi o partido eleitoralmente mais fraco do Paraná da época da Primeira República. No início dos anos 1920, a cena política desse estado foi marcada pela redução do rol de apoiadores da oposição. Assim, o surgimento do PRL não estimulou a emergência de novos personagens no jogo eleitoral do estado. Os novatos que pertenciam a essa grei logo perderam espaço para indivíduos que, havia tempos, exerciam posições destacadas nos quadros da oposição regional. Desse modo, nessa época não houve renovação significativa no grupo de líderes políticos do Paraná.

A terceira constatação ressalta que, após a dissolução do PRL, a maior parte dos seus dirigentes se desligou da cena política. Uma parcela desses dirigentes desempenhou circunstancialmente cargos comissionados e eletivos. A desagregação política entre os próceres do PRL foi irreversível. Foi pouco duradoura a tentativa desses novatos de manter em atividade um partido, difundir um ideário programático e combater o predomínio da agremiação oficial.

\section{Referências}

ALVES, Alessandro Cavassin. A Província do Paraná: a classe política, a parentela no Governo (1853-1889). 2014. Tese (Doutorado em Sociologia) - Setor de Ciências Humanas, Programa de Pós-Graduação em Sociologia, Universidade Federal do Paraná, Curitiba, 2014. Disponível em: https://hdl.handle.net/1884/35972. Acesso em: 12 jan. 2021.

ANTONACCI, Maria Antonieta. RS, as oposições e a Revolução de 23. Porto Alegre: Mercado Aberto, 1981.

BOIA, Wilson. Alceu Chichorro. Curitiba: SEEC, 1998.

BORGES, Vera Lúcia Borgéa. Morte na República: os últimos anos de Pinheiro Machado e a política oligárquica (1909-1915). Rio de Janeiro: IHGB, 2004. 
BRITO, Jonas. Um Ás na Mesa do Jogo: a Bahia na história política da I República. Salvador: UFBA, 2019.

CARNEIRO, Newton. As artes gráficas em Curitiba. Curitiba: Paiol, 1976.

CASSOL, Ernesto. Política tributária do Paraná na Primeira República, 1890-1930. 1973. Dissertação (Mestrado em História) - Setor de Ciências Humanas, Programa de PósGraduação em História, Universidade Federal do Paraná, Curitiba, 1973. Disponível em: https://hdl.handle.net/1884/24650. Acesso em: 12 jan. 2021.

CHACON, Vamireh. História dos partidos brasileiros. Brasília: UnB, 1985.

CHARLE, Christophe. Prosopografia ou biografia coletiva: balanço e perspectivas. In: HEINZ, Flávio (Org.). Por outra história das elites. Rio de Janeiro: FGV, 2006. p. 41-54.

COSTA, Odah Guimarães. Ação empresarial do Barão do Serro Azul. Curitiba: Grafipar, 1981.

DAGOSTIM, Maristela Wessler. A República dos Conselhos: um estudo sobre a transformação do perfil da política paranaense (1930-1947). 2011. Dissertação (Mestrado em Ciência Política) - Setor de Ciências Humanas, Programa de Pós-Graduação em Ciência Política, Universidade Federal do Paraná, Curitiba, 2011. Disponível em: https://hdl.handle.net/1884/25907. Acesso em: 12 jan. 2021.

FERREIRA, Marieta de Moraes. A Reação Republicana e a crise política nos anos 1920. Estudos Históricos, Rio de Janeiro, v. 6, n. 11, p. 9-23, 1993. Disponível em: https://bibliotecadigital.fgv.br/ojs/index.php/reh/article/view/1953. Acesso em: 15 fev. 2021.

FERREIRA, Marieta de Moraes. Em busca da Idade de Ouro: as elites políticas fluminenses na Primeira República (1889-1930). Rio de Janeiro: UFRJ/Tempo Brasileiro, 1994.

FIGUEIREDO, Vítor Fonseca. Voto e competição política na Primeira República: o caso de Minas Gerais (1889-1930). Curitiba: CRV, 2017.

GLASSER, Roberto. Discursos pronunciados nas sessões legislativas de 1914-1915. Curitiba: Requião, 1955.

GOULART, Mônica Helena. A dança das cadeiras: análise do jogo político na Assembleia do Paraná (1889-1930). Jundiaí: Paco, 2014.

GUIMARÃES, Manuel de Alencar. Política do Paraná. Curitiba: Edição do Autor, 1915.

IORIO, Regina Saboia. Intrigas \& novelas: literatura e literatos na Curitiba da década de 1920. Tese (Doutorado em História) - Setor de Ciências Humanas, Universidade Federal do Paraná, Curitiba, 2004. Disponível em: https://hdl.handle.net/1884/27153. Acesso em: 13 jan. 2021.

NEGRÃO, Francisco. Genealogia paranaense. Curitiba: Imprensa Oficial, 2004. v. 1, 2.

NOLL, Maria; TRINDADE, Helgio. Estatísticas eleitorais do Rio Grande da América do Sul (1823-2002). Porto Alegre: UFRGS, 2004. 
OLIVEIRA, Ricardo Costa de. Notas sobre a política paranaense no período 1930 a 1945. Revista de Sociologia e Política, Curitiba, n. 9, p. 47-56, dez. 1997. Disponível em: https://revistas.ufpr.br/rsp/article/view/39297. Acesso em: 12 jan. 2021.

PRADO, Maria Coelho. A democracia ilustrada: o Partido Democrático de São Paulo (1926-1934). São Paulo: Ática, 1986.

RIBEIRO, Paula Vanessa Paz. "A terceira estrela da federação": a bancada gaúcha no contexto político-eleitoral dos anos 1920 a 1924. 2019. Tese (Doutorado em História) Instituto de Filosofia e Ciências Humanas, Universidade Federal do Rio Grande do Sul, Porto Alegre, 2019. Disponível em: http://hdl.handle.net/10183/206483. Acesso em: 14 jan. 2021.

RICCI, Paolo (Org.). O autoritarismo eleitoral dos anos trinta e o Código Eleitoral de 1932. Curitiba: Appris, 2019.

SÁ PINTO, Surama Conde. Só para iniciados: o jogo político na antiga capital federal. Rio de Janeiro: Mauad, 2011.

SACCOL, Tassiana Maria Parcianello. De líderes históricos à opositores: as dissidências republicanas e o jogo político regional (Rio Grande do Sul, 1890-1907). 2018. Tese (Doutorado em História) - Escola de Humanidades, Pontifícia Universidade Católica do Rio Grande do Sul, Porto Alegre, 2018. Disponível em: http://tede2. pucrs.br/tede2/handle/tede/8113. Acesso em: 23 jan. 2022.

STONE, Lawrence. Prosopografia. Revista de Sociologia e Política, Curitiba, v. 19, n. 39, p. 115-137, 2011. Disponível em: https://revistas.ufpr.br/rsp/article/view/31689. Acesso em: 13 jan. 2021.

ZULINI, Jaqueline Porto. Modos do bom governo na Primeira República brasileira: o papel do Parlamento no regime de 1889-1930. Tese (Doutorado em Ciência Política) Faculdade de Filosofia, Letras e Ciências Humanas, Universidade de São Paulo, São Paulo, 2016. https://doi.org/10.11606/T.8.2016.tde-02122016-121222 